\title{
Globalization in the Aftermath of the Crisis
}

\author{
Fabio Ghironi ${ }^{1} \cdot$ Andrei Levchenko $^{2}$
}

Published online: 16 August 2018

(C) International Monetary Fund 2018

The global crisis of 2008-2009 was accompanied by large disruptions in international trade and capital flows. Trade fell so much that the moniker "great trade collapse" was coined to refer to the dynamics of imports and exports between the end of 2008 and early 2009. The rebound was similarly fast, but the pace of trade growth since the initial recovery from the crisis has remained subdued. Capital flows (for instance, foreign direct investment) are similarly still far from the rapid growth experienced between the mid-1990s and 2008. Meanwhile, the governments of several countries have been faced with the challenge of managing large flows of migrants and refugees displaced by famine, economic crisis, and conflict. The crisis that happened ten years ago appears to have represented a long-lasting setback for globalization, casting a darkening shadow also in the form of populist governments that make no secret of their penchant for protectionism, aversion to foreign investment, and rejection of immigration.

Against this background, the IMF, IMF Economic Review, and Bank Negara Malaysia (BNM) jointly organized a conference on "Globalization in the Aftermath of the Crisis." The conference took place in Kuala Lumpur, Malaysia, on July 25-26, 2017. This issue of the review features some of the papers presented at the conference. Below we summarize their key contributions.

The Keynote Address was delivered by Kevin O'Rourke (Oxford University). As an expert on economic history, Kevin compares the trade collapses of the Great Depression and the Great Recession. The commodity composition of the two collapses was quite similar, but the latter one was much sharper due to the spread of manufacturing across the globe during the intervening period. The wider diffusion

Fabio Ghironi ghiro@uw.edu

1 Seattle, USA

2 Ann Arbor, USA 
of manufacturing production across countries also meant that the trade collapse was more geographically balanced in the latter episode. Protectionism was much more severe during the 1930s than after 2008, and-in the UK case at least-it helped to skew the direction of trade away from multilateralism and toward the British Empire. Kevin concludes that this had dangerous political consequences.

"The Slowdown in Global Trade: A Symptom of A Weak Recovery?" by Aqib Aslam, Emine Boz, Eugenio Cerutti, Marcos Poplawski-Ribeiro, and Petia Topalova (all IMF) documents the slowdown in global trade growth between 2012 and 2016 relative both to its strong historical performance and to overall economic growth. Empirical findings suggest that the overall weakness in economic activity, particularly investment, has been the primary restraint on trade growth, accounting for over 80 percent of the decline in the growth of the volume of goods trade between 2012-2016 and 2003-2007. However, other factors also weighed on trade in recent years, especially in emerging market and developing economies, as evidenced by the non-negligible role attributed to trade costs by the structural model employed in the paper.

"Financial Frictions and Trade Dynamics" by Paul Bergin (University of California at Davis), Ling Feng (Shanghai University of Finance and Economics), and Ching-Yi Lin (National Tsing Hua University) emphasizes instead that the financial shock of 2008-2009 left a persistently slower growth rate in trade. Under certain conditions, a transitory financial shock significantly reduces the incentive of firms to make the investments required to enter export markets. This generates long-lasting effects on the range of goods exported and hence overall trade. Endogenous capital structure decisions by firms in response to financial shocks, and firm entry investment that requires traded goods play an important role in generating the mechanism. This mechanism provides an example of how firm dynamics can serve as a potent propagation mechanism, generating very long-lasting effects of transitory macroeconomic shocks.

Turning to capital flows, "Benchmarking Portfolio Flows" by John D. Burger (Sellinger School of Business, Loyola University Maryland), Francis E. Warnock (Darden Business School, University of Virginia), and Veronica Cacdac Warnock (Darden Business School, University of Virginia) creates a benchmark, a longerterm baseline path, around which actual flows fluctuate, for 45 countries for the 2000-2017 period. For emerging markets, there is a significant long-run relationship between actual portfolio flows and the authors' benchmark: Flows adjust strongly toward the benchmark, and the benchmark helps predict one-year-ahead changes in inflows. For advanced economies, the benchmark performs well in directional forecasting exercises. In practical terms, when assessing large movements in portfolio flows, it is informative to distinguish between movements toward the benchmark as opposed to movements away from the benchmark.

"The Changing Structure of Immigration to the OECD: What Welfare Effects on Member Countries?" by Michał Burzynski (University of Luxembourg), Frederic Docquier (Universite Catholique de Louvain), and Hillel Rapoport (Paris School of Economics and CEPII) investigates the welfare implications of two precrisis immigration waves (1991-2000 and 2001-2010) and of the post-crisis wave (2011-2015) for OECD native citizens. A general equilibrium model of the 20 
selected OECD member states accounts for the main channels of transmission of immigration shocks - the employment and wage effects, the fiscal effect, and the market size effect-and for the interactions between them. Three waves induce positive effects on the real income of natives; however, the size of these gains varies considerably across countries and across skill groups. In relative terms, the postcrisis wave induces smaller welfare gains compared to the previous ones. This is due to the changing origin mix of immigrants, which translates into lower levels of human capital and smaller fiscal gains. However, differences across cohorts explain a tiny fraction of the highly persistent, cross-country heterogeneity in the economic benefits from immigration.

In the Policy Corner of this issue, "Trade Policy Toward Supply Chains after the Great Recession" by Chad P. Bown (Peterson Institute for International Economics and CEPR) studies how trade policy treats intermediate inputs. Slow economic and trade growth during the recovery from the Great Recession, and recent political developments in the UK and USA pose a threat to cross-border supply chains and have thus brought this question to the forefront of policy circles. The paper investigates this question by examining new and detailed data on Group of 20 (G20) trade policy use through 2016, with a special emphasis on changes in policymaking behavior since 2010. First, there is no evidence that the G20 economies made significant changes to their applied import tariffs during this period. However, there has been a modest increase in import protection arising through other policy instruments of note such as temporary trade barriers (TTBs) in the form of antidumping, countervailing duties, and safeguards. More importantly, there is evidence of changes in how countries have applied their TTBs. TTBs were increasingly imposed on imports not only from China, but also from other countries, reversing a post-2001 trend. Furthermore, TTB protection has moved away from imports of final goods and toward imports of intermediate inputs. These shifts in policy have several potential contributing causes as well as economic consequences, including for cross-border supply chains.

We hope that you will enjoy reading this issue. The topics covered by the papers span several of the most important questions associated with the slowdown of globalization since the 2008-2009 crisis. The authors deploy state-of-the-art empirical and theoretical tools to perform their analyses. We are confident that these papers will become standard references for those who are interested in the international economic dynamics of the post-crisis decade and in the lessons for policy that can be drawn from them. We thank all the authors for their interesting contributions and all the discussants for their greatly helpful comments. We are also grateful to several referees for insightful comments and rapid service. Finally, our gratitude goes to Bank Negara Malaysia and the IMF for hosting and organizing the conference, to Tracey Lookadoo for her invaluable help throughout the entire process, and to Linda Tesar, Emine Boz, and the IMFER for giving us the possibility of putting together this issue.

Fabio Ghironi and Andrei Levchenko Guest Editors, IMF Economic Review 